Studia z Dziejów Średniowiecza, t. 23, 2019

\author{
Mirosław J. Leszka \\ (Katedra Historii Bizancjum, Uniwersytet Łódzki)
}

\title{
Obraz cara bułgarskiego Samuela w źródłach bizantyńskich (XII w.)
}

https://doi.org/10.26881/sds.2019.23.06

Keywords: medieval Bulgaria, Tsar Samuil, medieval Byzantium

Samuel, władca Bułgarii z przełomu X i XI w., to postać niewątpliwie znacząca w dziejach swojego kraju, która odcisnęła wyraźne piętno na jego relacjach $\mathrm{z}$ cesarstwem bizantyńskim ${ }^{1}$. To on rzucił wyzwanie Bizantyńczykom, którzy w 971 r. zajęli znaczną część Bułgarii. Przez kilka dekad najpierw wyrywał z rąk bizantyńskich bułgarskie tereny, a potem $\mathrm{z}$ wielką determinacją bronił swojego stanu posiadania. Dopiero kilka lat po jego śmierci (1014) bułgarskie państwo wpadło w ręce Bizantyńczyków (1018), co zapoczątkowała prawie stusiedemdziesięcioletni okres jego niebytu - czas bizantyńskiej niewoli.

Celem artykułu jest ukazanie, w jaki sposobu autorzy bizantyńscy w XII w. - a więc w czasie, kiedy ziemie bułgarskie od blisko wieku znajdowały się w obrębie cesarstwa bizantyńskiego i kiedy wydawało się, że będzie to stan trwały - przedstawiali Samuela ${ }^{2}$ i jaki mieli do niego stosunek.

Jeśli chodzi o korpus źródeł, który znalazł się w obrębie mojego zainteresowania, to pochodzi, jak już wskazano, z XII w. Nie jest on

1 Na temat Samuela i jego epoki literatura jest bardzo bogata. Pozwolę sobie w tym miejscu zacytować kilka najnowszych publikacji, w których czytelnik znajdzie odwołania do starszej literatury przedmiotu: G.N. Nikolov, Bălgarskijat car Samuil, Sofija 2014; P. Pavlov, Vekăt na car Samuil, Sofija 2014; Evropejskijat jugoiztok prez vtorata polovina na X-načaloto na XI vek. Istorija i kultura, săs. V. Gjuzelev, G.N. Nikolov, Sofija 2015; Chiljada godini ot bitkata pri Belasica $i$ ot smărtta na car Samuil (1014-2014), red. V. Gjuzelev, G.N. Nikolov, Sofija 2015; P.M. Strässle, Krieg und Kriegsfürung in Byzanz. Die Kriege Kaiser Basileios II. Gegen die Bulgaren (976-1019), Köln 2006; T. Tomov, Ključ 1014 g., Sofija 2015.

2 Na temat kwestii ukazywania Samuela w źródłach bizantyńskich pisał ostatnio P. Angelov, Car Samuil v predstavite na vizantijcite [w:] Evropejskijat..., s. 258-265. 
specjalnie rozległy. Najobszerniejsza relacja dotycząca Samuela znajduje się w dziele Epitome historion Jana Zonarasa ${ }^{3}$, w dużej mierze bazujacym na powstałym w drugiej połowie XI w. przekazie Jana Skylitzesa ${ }^{4}$. Została ona powtórzona w mocno uszczuplonej formie przez Michała Glykasa ${ }^{5}$. Pewne nowe elementy w porównaniu z relacją Zonarasa i Glykasa znajduja się w Materiałach historycznych Nikefora Bryenniosa ${ }^{6}$, Aleksjadzie Anny Komneny ${ }^{7}$ i Żywocie Nikona Metanoity ${ }^{8}$.

3 Ioannis Zonarae Epitome historiarum libri XIII-XVIII, ed. Th. Büttner-Wobst, Bonnae 1897 (dalej: Jan Zonaras). Dzieło obejmuje czasy od powstania świata do 1118 r. Zostało napisane niedługo po tym roku. Na temat Zonarasa i jego dzieła zob. m.in.: I. Grigoriadis, Linguistic and literary studies in the Epitome Historion of John Zonaras, Thessaloniki 1998; idem, A Study of the Prooimion of Zonaras' Chronicle in Relation to Other $12^{\text {th }}$-Century Prooimia, Bd. 91, „Byzantinische Zeitschrift” 1998, s. 327-341; T.M. Banchich, Introduction [w:] The History of Zonaras from Alexander Severus to the Death of Theodosius the Great, transl. idem, E.N. Lane, New York 2009, s. 1-19; Ch. Mallan, The Historian John Zonaras: Some Observations on His Sources and Methods, [w:] Les historiens grecs et romains: entre sources et modèles, eds. O. Devillers, B. Sebastiani, Bordeaux 2018, s. 353-366.

4 Ioannis Scylitzae Synopsis historiarum, rec. I. Thurn, Berlin 1973, s. 330 et seq. $\mathrm{Na}$ temat obrazu Samuela w tym źródle zob. J. Bonarek, Romajowie i obcy w kronice Jana Skylitzesa. Identyfikacja etniczna Bizantyńczyków i ich stosunek do obcych $w$ świetle kroniki Jana Skylitzesa, Toruń 2003, s. 149-156. Poza obręem swojej analizy pozostawiam uzupełnienia do dzieła Skylitzesa pochodzace od Michała, biskupa Dewola, a znajdujące się w rękopisie oznaczonym przez Thurna jako MS U i powstałe w początkach XII w. Nie stanowią one spójnej całości i są podporządkowane tak pod względem ideowym, jak i logiki narracji Skylitzesowi. Na ich temat zob. J. Ferluga, John Scylitzes and Michael of Devol [w:] idem, Byzantium on the Balkans. Studies on the Byzantine Administration and the Southern Slavs from the VII th to the XII ${ }^{\text {th }}$ Centuries, Amsterdam 1976, s. 337-344.

5 Michaelis Glycae Annales, ed. I. Bekker, Bonnae 1836 (dalej: Michał Glykas). Dzieło Glykasa, podobnie jak praca Jana Zonarasa, obejmuje czasy od powstania świata po 1118 r. O Glykasie i jego dziele zob m.in.: H. Eideneier, Zur Sprache des Michael Glykas, Bd. 61, „Byzantinische Zeitschrift” 1968, s. 5-9; Y. Papadogiannakis, Michael Glykas and the Afterlife in Twelfth-century Byzantium [w:] The Church, the Afterlife and the Fate of the Soul, eds. P. Clarke, T. Claydon, Woodbridge 2009, s. 130-142; L. Neville, Guide to Byzantine Writing, Cambridge 2018, s. 205-209.

$6 \quad$ Nicephore Bryennios, Histoire, ed. P. Gautier, Brussels 1975 (dalej: Nikefor Bryennios). Na temat Nikefora Bryenniosa ostatnio pisała L. Neville, Heroes and Romans in Twelfth-Century Byzantium: The "Material for History" of Nikephoros Bryennios, Cambridge 2012.

7 Annae Comnenae Alexias, rec. D.R. Reinsch, A. Kambylis, vol. 1-2, Berolini et Novi Eboraci 2001 (dalej: Anna Komnena). O Annie i jej Aleksjadzie powstała bogata literatura. Tu cytuje jedynie kilka nowszych pozycji: Anna Komnene and Her Times, ed. Th. Gouma-Peterson, New York 2000; P. Buckley, The Alexiad of Anna Komnene: Artistic Strategy in the Making of a Myth, Cambridge 2014; L. Neville, Anna Komnene: The Life and Work of a Medieval Historian, Oxford 2016

8 The Life of Saint Nikon, ed. F. Sullivan, Brookline 1987. Anonimowy $\dot{Z} y w o t$ św. Nikona, bizantyńskiego mnicha z X w., według części uczonych powstał w XII w. 
Informacje zawarte w powyżej wzmiankowanych źródłach, a dotyczące Samuela, skupiają się wokół dwóch podstawowych kwestii a mianowicie okoliczności przejęcia przez niego władzy oraz prowadzonych przez niego działań wojennych przeciw Bizancjum $-\mathrm{z}$ tego też względu na tych dwóch kwestiach skupię się w swoim wywodzie.

\section{Przejęcie władzy}

Wydaje się, że Bizantyńczycy uznawali władzę Samuela nad Bułgarami za legalna. Jan Zonaras jednoznacznie wskazuje, iż Bułgarzy przekazali ja po śmierci Jana Tzymiskesa czterem braciom: Dawidowi, Mojżeszowi, Aaaronowi, Samuelowi, którzy byli synami jednego z bułgarskich komesów i stąd zwano ich Komitopulami. Co szczególnie istotne, Bułgarzy mogli to uczynić, ponieważ Roman, jedyny pozostający przy życiu syn cara Piotra, któremu przysługiwało prawo dziedziczenia władzy ${ }^{9}$, nie mógł jej sprawować, był bowiem eunuchem ${ }^{10}$. Przejęcie samodzielnej władzy przez Samuela stanowiło następstwo śmierci jego braci. Jak pisze Zonaras ${ }^{11}$, za śmierć Aarona oraz jego rodziny Samuel był osobiście odpowiedzialny. Powodem zgładzenia Aarona miało być to, iż sprzyjał on Bizantyńczykom i sam dążył do władzy. Samuel-bratobójca został władcą Bułgarii. Jest znamienne, że Zonaras nie komentuje tego faktu. Nie przeszkadza mu ani przelew braterskiej krwi, ani to, co szczególnie zastanawia, że ofiarą Samuela był człowiek sprzyjający Bizantyńczykom.

(tak np. L. Jovčev, Žitie na Nikon Metanoite [w:] Grăcki Izvori na bălgarskata istorija, vol. VII, Sofija 1968, s. 147; P. Angelov, Car..., s. 261). Obiekcje, co do tej datacji, przedstawił F. Sullivan, wskazujacc na połowę wieku XI (s. 2-7) jako czasu napisania tego dzieła. Kwestia ta wymaga dalszych badań. Przyjmuję, iż nie jest wykluczone, że tekst ten powstał w I połowie XII w. Na temat św. Nikona zob. A. Louth, Greek East and Latin West. The Church AD 681-1071, New York 2007, s. 260-262.

9 Jan Zonaras, s. 547. Na temat zasad przekazywania władzy w Bułgarii zob. m.in. G.G. Litavrin, Princip nasledstvennosti vlasti $v$ Vizantii i $v$ Bolgarii $v$ VIIXI vv. [w:] Slavjane i ich sosedi, vol. 1, Moskva 1988, s. 31-33. J. Andreev, Joan Ekzarch i njakoi văprosi văv vrăzka s nasledjavaneto na carskata vlast $v$ srednovekovna Bălgarija [w:] Preslavska Knižovna Škola, vol. 1: Izsledvanija i materiali, săs. M. Tichova, P. Dimitrov, Sofija 1995, s. 308-316.

10 W Bizancjum eunuchowie nie mogli sprawować władzy cesarskiej (M.J. Leszka, Uzurpacje $w$ cesarstwie bizantyńskim w okresie od IV do połowy IX wieku, Łódź 1999, s. 15). Zonaras, jak można sądzić z jego narracji, uważał, że takie ograniczenie funkcjonowało także w Bułgarii.

11 Jan Zonaras, s. 548. 
Przekonanie wśród Bizantyńczyków, że Samuel był prawowitym władcą Bułgarii, potwierdza Anna Komnena, określając go mianem „ostatniego przedstawiciela dynastii bułgarskiej”, którego jednym z poprzedników miał być „cesarz Bułgarów Mokros”12. Uczona cesarzowa popełnia w tym miejscu błąd. Bez względu na to, kim był wzmiankowany Mokros (może chan Krum, 796/803-814) ${ }^{13}$, Samuel nie był ostatnim przedstawicielem dynastii Komitopulów rządzącej w Bułgarii, po nim sprawowali władzę jeszcze Gabriel Radomir i Jan Władysław, ale z pewnością był jej najwybitniejszym przedstawicielem. Dziwić może ten brak orientacji u Anny Komneny, w której żyłach płynęła przecież krew Komitopulów ${ }^{14}$. Podobnym brakiem dokładnej wiedzy o Komitopulach wykazywał się również Nikefor Bryennios, mąż Anny, który co prawda konsekwentnie nazywał Samuela bazyleusem Bułgarów ${ }^{15}$, ale błędnie pisał, że miał on syna Trojana (Troiannes), który w rzeczywistości był synem Jana Władysława, jedynego pozostającego przy życiu potomka Aarona, brata Samuela. Nie ma dla mnie znaczenia, czym sa spowodowane te nieścisłości Anny i Nikefora. Istotne jest to, że oboje uznawali Samuela za cesarza Bułgarów ${ }^{16}$.

Z jednej strony widać w bizantyńskich tekstach z XII w. uznanie legalności władzy Samuela nad Bułgarami, ale z drugiej przewija się myśl, że był on buntownikiem, który wystapił przeciw Bizancjum. Myśl o Samuelu jako buntowniku, tak wyraźnie zaznaczoną w jedenastowiecznych bizantyńskich źródłach ${ }^{17}$, można, jak sądzę, odszukać w porównaniu go, oraz innych bułgarskich władców, przez Annę Komnenę do Sedecjasza, biblijnego władcy Judy ${ }^{18}$, który sprawował

12 Anna Komnena, VII, 3, 4 (tłumaczenie Anna Komnena, Aleksjada, z języka greckiego przełożył, wstępem opatrzył O. Jurewicz, t. 2, Wrocław 2005, s. 292).

13 I. Dujčev, Săščinskoto značenie na imeto mokros u Anna Komnena [w:] idem, Bălgarskoto srednovekovie, Sofija 1972, s. 194 et seq.

14 Anna była praprawnuczką cara Jana Władysława (1015-1018). Irena Dukajna, jej matka, była córką Marii z Bułgarii, córki Trojana, syna cara Jana Władysława.

15 Nikefor Bryennios, II, 6; III, 6.

16 Jeśli chodzi o tytułowanie Samuela przez innych autorów, to Jan Zonaras (s. 558) nazywa Samuela „eksarchontos Boulgaron”. Warto zaznaczyć, że Samuel stosunkowo często nie jest w ogóle tytułowany, co dobrze wpisuje się w tendencje obecne w literaturze bizantyńskiej w odniesieniu do innych władców, zob. P. Anelov, Car..., s. 261, 262. Generalnie na temat tytułowania władców bułgarskich w bizantyńskiej literaturze zob. M.J. Leszka, Wizerunek władców pierwszego państwa butgarskiego w bizantyńskich źródłach pisanych (VIII-pierwsza połowa XII wieku), Łódź 2003, s. 19-20, 61-63, 76, 131-134.

17 P. Angelov, Car..., passim.

18 Anna Komnena, VII, 3, 4. 
swoje rządy z woli Babilończyków. Po tym, jak wystapił przeciw swoim mocodawcom, został surowo przez nich ukarany (oślepiony i uwięziony) ${ }^{19}$. A stało się to z woli Boga. Dla Anny Samuela Bóg ukarał, podobnie jak Sedecjasza, za to, że wystapił przeciw Bizantyńczykom. Michał Glykas, idąc, prawdopodobnie za przekazem Jana Skylitzesa i Jana Zonarasa, pisze o Bułgarach, którzy na wieść o śmierci Jana Tzymiskesa zbuntowali się ${ }^{20}$, jak można mniemać, przeciw Bizantyńczykom. Istotny jest też komentarz Michała, iż od ich wystapienia rozpoczą się czas wojen i rozlewu krwi.

Bizantyńscy autorzy zastanawiali się, dlaczego Samuelowi udało się po przejęciu samodzielnej władzy nad Bułgarami rozszerzyć swój stan posiadania, ${ }^{21}$ znajdując dość proste wytłumaczenie, skądinąd chyba prawdziwe, że było to następstwem słabości cesarstwa bizantyńskiego, które w tym czasie było areną walki o władzę między Bazylim II a arystokratycznymi rodami.

Dwunastowieczni pisarze bizantyńscy nie pisali, jakim Samuel był władcą. Wydaje się, że można doszukiwać się ich oceny w opisie finału jego życia. Okoliczności śmierci Samuela, która nastapiła po tym, jak miał zobaczyć swoich wojów oślepionych z rozkazu Bazylego II ${ }^{22}$ po klęsce pod Kleidion (1014), można odczytać jako wyraz zwiąku Samuela z rządzonym ludem. Bułgarski władca doznał wówczas wstrząsu, który doprowadził go do udaru czy ataku serca, co w konsekwencją spowodowało jego zgon - oto dobry władca przejmujacy się losem swoich poddanych nie może znieść ich cierpienia. To jest oczywiście jedna z możliwych interpretacji tego wydarzenia. Na inną wskażę poniżej.

\section{Samuel jako wódz}

Bizantyńscy autorzy XII w. zwrócili uwage na militarną aktywność Samuela. $Z$ tytułu wieloletnich zmagań wojennych bułgarsko-bizantyńskich to ona bowiem wysuwała się na plan pierwszy. Jednak

19 Jr 52, 3-11.

20 Michał Glykas, s. 557; zob. przekaz Jana Skylitzesa, s. 256 i 328; komentarz J. Bonarek, Romajowie..., s. 149, przyp. 277.

21 Jan Zonaras, s. 548.

22 Ibidem, s. 564; Michał Glykas, s. 578. Warto odnotować sugestię Petyra Angelowa (Car..., s. 260), że oślepienie było karą za bunt Bułgarów. Nieodparcie nasuwa się w tym kontekście porównanie Samuela i innych bułgarskich władców z Sedecjaszem jako buntownikiem oślepionym przez Babilończyków. 
jedynie anonimowy autor Żywota św. Nikona bezpośrednio odniósł się do walorów Samuela jako żołnierza. Określił go mianem niepokonanego i niedoścignionego $\mathrm{w}$ męstwie ${ }^{23}$. Trzeba jednak zaznaczyć, że ta bardzo pozytywna charakterystyka bułgarskiego władcy (niewątpliwie mająca odzwierciedlenie w rzeczywistości) miała służyć, jak się wydaje, jedynie uwypukleniu zasług Bazylego II, który potrafił pokonać tak wybitnego wojownika ${ }^{24}$. Bizantyńskiego władcę anonimowy autor nazywa najszczęśliwszym spośród wszystkich cesarzy, podkreśla długość jego rządów i liczne zwycięstwa nad nieprzyjaciółmi. Jako przykład pokonanego wroga wskazuje właśnie Samuela, który nie dość, że został zwyciężony przez Bazylego, to jeszcze rządzony przez niego lud wykrwawił się i musiał uznać bizantyńską zwierzchność.

W innych bizantyńskich źródłach XII w. można odnaleźć takie samo dążenie do wykazania wyższości Bazylego (czy szerzej rzecz ujmując, Bizantyńczyków) nad Samuelem i jego poddanymi, ale jest ono realizowane w inny sposób. Owszem, Zonaras wskazywał, że Samuel zwyciężał w zmaganiach z Rzymianami, ale nie świadczyło to o jego militarnym kunszcie czy męstwie jego wojów, ale o błędach popełnionych przez samych Bizantyńczyków, wewnętrznych tarciach i ich zaangażowaniu na innych frontach. I tak bułgarskie sukcesy odnoszone w okresie poprzedzającym bitwę w Bramie Trajana (w roku 986) były, zdaniem Zonarasa, efektem zmagań Bazylego ze Sklerosem ${ }^{25}$, a zwycięstwo Samuela w tej bitwie stanowiło z jednej strony konsekwencję pochopnej decyzji cesarza o wyruszeniu bez należytego przygotowania przeciw Bułgarom, z drugiej zaś było wynikiem intrygi, którą uknuł Stefan, domestyk scholon, zwany Konstostefa$n^{26}{ }^{26}$. Miał on poinformować Bazylego II, że Leon Melissenos zamierza przejąć władzę cesarską i właśnie w tym celu udał się do Konstantynopola. Cesarz w tej sytuacji zrezygnował z walki z Samuelem i rozkazał odwrót. Moment nieuporządkowanego wycofywania się bizantyńskich wojsk wykorzystał Samuel, który uderzył na Bizantyńczyków i zmusił ich do ucieczki.

Z kolei zdobycie Adrianopola przez Samuela (1003) było zdaniem Zonarasa możliwe tylko dlatego, że Bazyli był wówczas zajęty

\footnotetext{
Żywot św. Nikona, s. 43.

P. Angelov, Car..., s. 261.

Jan Zonaras, s. 548. Chodzi o uzurpatora Bardasa Sklerosa.

Ibidem, s. 548-549.
} 
obleganiem Bdine (Widyń) i nie mógł skuteczne interweniować ${ }^{27}$. Ze współczesnego punktu widzenia takie działanie Samuela należy z pewnością uznać za przejaw jego umiejętności jako wodza i nie można mu z tego powodu czynić zarzutu.

Bizantyńscy autorzy XII w. - tak nie skorzy do uznania talentów militarnych Samuela - nie szczędzą mu słów krytyki. I tak na przykład Zonaras zarzuca Samuelowi tchórzostwo (m.in. przed bitwa w Bramie Trajana miał zająć wierzchołki okalających gór z obawy przed otwartym starciem i walką wręcz), brak przezorności i beztroskę $^{28}$. O tych ostatnich moga świadczyć choćby następujące przykłady. W przededniu bitwy nad rzeką Sperchejos (997) Samuel źle ocenił sytuację, że z powodu podniesienia poziomu wód rzeki, będącego następstwem ulewnych deszczów, Bizantyńczycy nie podejmą działań przeciw Bułgarom i nie przeprawią się przez rzekę. Nikefor Uranos, bizantyński wódz, znalazł jednak bród, noca przekroczył rzekę i zaatakował pogrążonych we śnie Bułgarów. Wielu z nich zginęło. Samuel i jego syn się uratowali, ponieważ udawali martwych ${ }^{29}$. Takiego zachowania nie można zaliczyć do chlubnych. Podobnie rzecz się miała w bitwie nad Aksios/Wardarem (1004), kiedy to Samuel znów nie zachował ostrożności, uważając, że rzeka, która właśnie wylała, stanowi przeszkodę nie do przejścia. Wojska cesarskie i tym razem znalazły bród i niespodziewanie zaatakowały Bułgarów. Wielu z nich zginęło, a Samuel uciekł z pola bitwy ${ }^{30}$.

Bizantyńscy autorzy przypisują Samuelowi nie tylko brak odwagi, podstępność, ale okrucieństwo i chciwośćc ${ }^{31}$. Tym samym wpisują się w mocno obecną w bizantyńskiej literaturze tendencję ukazywania Bułgarów i ich władców nawet długo po chrystianizacji jako barbarzyńców. Tak właśnie wprost nazywa Samuela Zonaras ${ }^{32}$. O Bułgarach jako barbarzyńcach walczacych z Bazylim pisze inny dwunastowieczny autor - Konstantyn Manasses ${ }^{33}$.

27 Jan Zonaras (s. 560) pominął fakt, zanotowany przez Jana Skylitzesa (zob. J. Bonarek, Romajowie..., s. 150), że Bułgarzy zdobyli Adrianopol w dzień świąteczny.

28 Jan Zonaras, s. 549.

29 Ibidem, s. 558-559.

30 Ibidem, s. 560.

31 Źródła wzmiankują o łupieniu przez Bułgarów bizantyńskich terenów, zob. ibidem, s. 548,558 .

$32 \quad$ Ibidem, s. 548.

33 Constantini Manassis Breviarium Chronicum, 5895, 5908, ed. O. Lampsidis, vol. 1, Athenis 1996. Na temat Konstantyna Manassesa ostatnio: L. Neville, Guide..., s. 200-204; The Chronicle of Constantine Manasses, translated with commentary and 
O słabości charakteru Samuela mogą również świadczyć, przedstawione już powyżej, okoliczności jego śmierci. Nie był on w stanie mężnie i z godnościa, jak przystało wodzowi i wojownikowi, znieść tego, co się stało udziałem jego żołnierzy w wyniku klęski pod Kleidion. Nie jest wykluczone, że na taka właśnie refleksję u swojego czytelnika liczył Jan Zonaras, zreszta powtarzajacy w tym przypadku prawie dosłownie przekaz Jana Skylitzesa. Jest to jednak jedynie przypuszczenie, które nie odrzuca wcześniej wskazanej innej możliwości odczytania tego przekazu.

$* * *$

Podsumowując powyższe rozważania, chciałbym zwrócić uwagę, że na obraz Samuela w bizantyńskich tekstach XII w. rzutuje z jednej strony obecna w nich tendencja do pomniejszania sukcesów wrogów Bizantyńczyków z drugiej zaś opisywany w późniejszych tekstach fakt, że Bułgarzy stali się poddanymi bizantyńskiego władcy i część z nich weszła do elity bizantyńskiego społeczeństwa, niekiedy łącząc się $\mathrm{z}$ nią więzami rodzinnymi. W tej sytuacji lepiej było być powiązanym z bazyleusem Samuelem niż z Samuelem barbarzyńca.

\section{Abstract}

The portrayal of the Bulgarian Tsar Samuel in the twelfth-century Byzantine sources

Samuel, the ruler of Bulgaria from the turn of the tenth and eleventh centuries is without a doubt a significant figure in the history of his country, having left a clear mark on its relations with the Byzantine Empire. It was he who challenged the Byzantines, who occupied a considerable part of Bulgaria in 971. Over the course of several decades, he was first wrenching Bulgarian territories from the Byzantine hands and subsequently defended his possessions with great determination. It was only several years after his death (1014) that the Bulgarian state fell into Byzantine hands (1018), ushering an almost hundred and seventy year period of its nonexistence - the time of Byzantine captivity.

introduction by L. Yuretich, Liverpool 2018, s. 1-3. Należy odnotować, że Konstantyn Manasses nie wzmiankuje imienia Samuela w passusie poświęconym walkom cesarza Bazylego II z Bułgarami. 
Information included in the $12^{\text {th }}$-century Byzantine sources (Nicephor Bryennios, Anna Komnene, John Zonaras, Michael Glykas, The Life of Nikon Metanoeite"), analysed in the present article and relating to Samuel are focused on the two fundamental questions, specifically the circumstances in which he had taken the reins of power and the military activity he conducted against Byzantium. The portrayal of the Bulgarian ruler included therein was on the one hand influenced by the trend present in the Byzantine literature to diminish the successes of the Empire's enemies by indicating their causes were to be found on the Byzantine side, and on the other by the fact that the Bulgarians became subjects of the Byzantine ruler. Some of them entered into the elite of the Byzantine society, sometimes through familial connections. In these circumstances, it was better to be related to Samuel the Basileus, rather than to Samuel the barbarian. 